\title{
Early and Forced Child Marriages in Rural Western Nepal
}

\author{
Pitambar Acharya \\ Tribhuvan University, Nepal \\ Benjamin Welsh \\ Morgan State University, United States
}

\begin{abstract}
This research assessed the determinants, consequences and preventive measures of early and forced child marriage (ECM). This mixed method surveyed 167 households taking $15 \%$ sample from the clusters of three wards of Badhaiyatal Rural Municipality in Bardiya and Dullu Municipality in Dailekh of Western Nepal. Besides household survey, six Focus Group Discussions (FGDs), 16 Key Informant's Interviews (KIIs), and 12 In-depth-Interviews (IDIs) were also conducted. There was the prevalence of ECM in $94 \%$ of the total sampled households. Majority (64\%) of the marriages had taken place at the age of 15-19 years. Besides, about 23\% of the marriage had occurred at 10-14 years. Average age at marriage was 16.5 years. Lack of awareness, self-elopement, misuse of social media, and parents' perception of daughters as burden were some contributing factors of ECM. Unsafe sexual behavior, unwanted pregnancy and its risk to unsafe abortion, maternal and child mortality, deprivation of education and selfdependence and violence were some effects of ECM. Recommendations to address ECM and curb its negative effects are presented.
\end{abstract}

Keywords: child marriage, abortion, violence, ECM, Nepal

Marriage is the legal and socio-cultural bond between persons to live together with the role of husband and wife. It is a vital event and fundamental right that must occur with the decision of persons themselves. Indeed, the right to a 'free and full' consent to marriage is recognized by the 1948 Universal Declaration of Human Rights (Save the Children, 2014). Anything short of mutual consent is considered human rights violation (Plan International, Save the Children \& World Vision International Nepal, 2014). Alejos (2015 cited in Dangi, 2017) mentions that Convention on the Rights of the Child and International Conference on Population and Development (ICPD) both made commitments to eliminate harmful traditional practices such as child marriage and child pregnancy.

Marriage before the legal age of consent is termed 'early and forced child marriage' (ECM). ECM is considered a global human rights issue because it is endured by millions of people in myriad countries around the world and because it contributes to human trafficking in developing countries. ECM often ruins the lives of the adolescent or pre-adolescent female victims physically and psychologically, depriving them of their childhoods, leaving them 
vulnerable to abuse and exploitation. Men who participate in ECM frequently submit their young female-brides to emotional, domestic, and sexual violence, creating life-threatening conditions which jeopardize their wives' emotional, sexual and reproductive well-being and putting them at a higher risk of exposure to STIs such as HIV. ECM also limits its victims' life choices since a girl's education usually stops once married or after childbirth, ruining her chances of a vocation or career. Thus, at the community or state level, ECM strains health care services and perpetuates the cycle of poverty (Alejos, 2015 cited in Dangi, 2017).

Pregnancy- and birth-related complications drive the human costs of ECM even higher. Pregnancy-related complications include uterine prolapse, a hernia-like condition involving the uterus that can be life-threatening. Birth-related complications include infant and maternal mortality and malnutrition of mother and child. ECM victims are also prone to post-partum psychological problems, including depression and suicide because they are neither physically nor mentally prepared to be mothers. ECM is a serious problem in developing countries such as Nepal, India and Bangladesh.

According to UNFPA (2013), pregnancy and childbirth are a leading cause of death for older adolescent females in developing countries. Adolescents who become pregnant tend to be from lower-income households and be nutritionally depleted. Health problems are more likely if a girl becomes pregnant too soon after reaching puberty. Adolescent pregnancies occur with varying frequency across regions and countries, within countries and across age and income groups. The girls who are poor, live in rural or remote areas and who are illiterate or have little education are more likely become pregnant than their wealthier, urban, educated counterparts. Similarly, girls from an ethnic minority or marginalized group lack choices and opportunities in life, have limited or no access to sexual and reproductive health services and become pregnant. Besides, a girl, worldwide, is more likely to become pregnant under circumstances of social exclusion, poverty, marginalization and gender inequality, where she is unable to fully enjoy or exercise her basic human rights, access to health care, schooling, information, services and economic opportunities.

\section{EARLY AND FORCED CHILD MARRIAGE IN NEPAL}

\section{Governmental Prevention Efforts}

ECM is illegal in Nepal. The Nepali government has set the legal age for marriage at 20 years with an amendment of Civil Code (Muluki Ain). Nepal has taken ECM as a violation of child rights. The Constitution of Nepal, in Article 39 has established as the child right against child marriage, illegal trafficking, kidnapping and bond (Bandhak). National Policy on Children 2069 BS has opposed ECM as an obstacle to child's right. It has emphasized the prevention of ECM through mobilization of governmental and non-governmental partner organizations to support the reporting and actions against child marriage. In addition, the government of Nepal has also formulated and implemented the National Action Plan for Adolescents to reduce the harm social practices and discrimination and bring the ECM survivors to mainstream of formal education (MWCSW, 2016). Nepal has been signatory in various international treaties and conventions regarding child right and ECM. Nepal has endorsed various international legal documents like the Child Right Convention 1989, the Convention on the Elimination of All Forms of Discrimination against Women (CEDAW) 1979, International Covenant on Economic, Social and Cultural Rights 1966, Convention against Torture 1984, Program of Action adopted 
at International Conference on Population and Development 1994, Beijing Declaration and platform for action 1995 and other SAARC level documents related to the protection and promotion of child rights. Globally, child marriage had been identified as the hindrance achieving the Millennium Development Goals (MDGs) and the issue of eradicating child marriage has been included in the agenda of Sustainable Development Goals (SDGs), 2016-2030 with high priority. Nepal is also serious towards it (MWCSW, 2016).

\section{Nepali ECM Continues}

Despite prevention efforts of the government, the prevalence of ECM is very high in Nepal. Nepal is in the third position after India and Bangladesh when it comes to ECM. According to the 2011 census, more than 750,000 Nepali girls were married between 10 and 14 years of age. Two out of 10 women of age 15-49 years were first married before the age of 15 and five out of 10 women aged 20-49 years were first married before the age of $18.41 \%$ of Nepali girls are married before the age of 18 (NDHS, 2011) where 73\% are married by 19 years old. ECM varies between regions to some extent. 53\% of child marriage happens in Midwest Nepal where concentrations of Dalits, Muslim, Madheshi and Tharu, among other marginalized populations, are found. There, more girls are married before 18 years because of hypermasculinefriendly socio-cultural values, gender discrimination, persistent poverty, illiteracy etc. (Ministry of Women, Children and Social Welfare [MWCSW], 2016; Aawaaj, 2016). Fertility and childbirth statistics in Nepal follow a similar regional profile.

$17 \%$ of Nepali girls and young women between the ages $15-19$ are reported as bearing children (NDHS, 2016). And, the proportion of teenagers who are bearing children rises rapidly with age, from $2 \%$ at age 15 , to $36 \%$ at age 19 . Rural teenagers tend to start childbearing earlier than urban teenagers. The fertility rate for young women aged 15-19 is 125 per thousand $(12.5 \%)$, where the fertility rate for young women aged $20-24$ years is 209 per thousand $(20.9 \%)$ in rural areas of Nepal (Ministry of Health, Nepal; New ERA; and ICF, 2017).

\section{Recent Prevention Efforts}

Needless to say, the Nepali government is gravely concerned by the ongoing prevalence of ECM and its consequences, in spite of the intensive efforts to reduce it. Besides the Children's Rules, 1995, specifically entrusts the Central Child Welfare Board with the duty to identify measures to eliminate child marriage and encourage and support the appropriate government agencies and non-governmental organizations to implement those measures. Similarly, the Local Self Governance Act, 1999, obligates local-level governance bodies to adopt necessary programs for the protection of women and children with allocation of at least 10 percent of their budgets for programs and projects that may be used in formulating specific programs to end child marriage in Nepal (The Centre for Reproductive Rights, 2016).

Nepal has also adopted the National Strategy to End Child Marriage in Nepal, 2016. It provides detail policy to promote legal accountability with the vision of 'child marriage-free Nepal' and aim to end child marriage by 2030. Taking a multi-sectoral approach to end child marriage, the Strategy incorporates six pillars, namely: empowerment of girls and adolescents; quality education for girls and adolescents; engaging boys, adolescents, and men; mobilizing families and communities; access to services; and strengthening and implementing laws and policies. Effective implementation and reform of existing legal provisions on child marriage is one of the objectives of the Strategy maintaining international human rights standards (The 
Centre for Reproductive Rights, 2016). Besides, NPC (2017), under the sub-heading 'Children and Adolescents' in the Fourteenth Plan, has focused on the extension of awareness program up to community level to create awareness against early marriage, child marriage and forced marriage. CBS (2016), in its NMICS Report, mentioned that the situation calls for investments in girls through giving them access to education and health services, developing their social and economic assets and ensuring that they can postpone their marriage until they are ready (UNFPA, n. d.).

It seems that Government of Nepal has taken the issue of ECM seriously; however, there are some gaps in prevailing other laws, policies and their effective implementation. Therefore, child marriage is gaining its continuum in Nepal despite the constitutional guarantees and legal prohibition due to ineffective implementation of existing laws prohibiting the practice, normative gaps and inconsistencies, continuing impunity for the guilty parties and lack of access to justice for victims. Therefore, failure to report cases of child marriage, poor knowledge of the law and legal age of marriage, lack of harmonization between relevant laws, limited knowledge among law enforcement agencies about their roles, lack of legal accountability for not taking required actions, limited prosecution of child marriage, lack of support mechanisms for victims are some existing challenges in law enforcement that need to be addressed to ensure the state accountability for ending impunity regarding ECM (The center for Reproductive Right, 2016).

\section{This Study: ECM in Nepal Today}

This study "Early and forced child marriage in rural western Nepal" has been conducted in order to assess the situation of ECM, determinants, consequences and the preventive measures. It is hoped that this study will provide bench mark data/information for the government and nongovernment sectors in order to implement the project and its monitoring regarding ECM. It can help to frame the baseline and end line data for a project related to ECM. This research can be used as reference by policy makers, I/NGOs and amateur academics who want to work and study in the domain of ECM and child protection. This research report can be useful to local government authority, right activists as well as gender advocates.

\section{LITERATURE REVIEW}

Davis and Blake (1956 cited in Bhende, \& Kanitkar, 1994) stated marriage as one of the "intermediate variable" of fertility. They included age at marriage as the age of entry into sexual union. Similarly, the Bongaart's model $(1978,1982)$ is a tool for examining the relative contribution of each of the four factors to the inhibition of fertility from its theoretical maximum. It is an aggregate fertility model describing the relationship between fertility and the four principal proximate determinants: marriage; contraception; induced abortion; and postpartum infecundability (or postpartum insusceptibility) (UNFPA, n.d.). In this way, age at marriage is one of the important determinants of the fertility.

'Early marriage' describes a marriage that occurs prior to the age of marriage recognized by law and the term 'forced marriage' implies the lack or incapacity to give consent on the part of child contracting party to marriage, due to minority. Often times rooted in a society's culture that attaches a great value to the virginity and chastity of women. The desire to protect the purity of girls forms another major cause of marriages at young age because the religious scriptures sanction that a girl can be married with proper rites only when she is a virgin. Among Brahmins, a father who could not marry his daughter before pre-puberty was believed to commit a sin 
(Vandana, 2017). Early marriage results the unwanted pregnancy and childbirth. According to UNFPA (2013), pregnancy and childbirth are the leading causes of death for older adolescent females in developing countries. The girls who are poor, live in rural or remote areas and who are illiterate or have little education more likely become pregnant than their wealthier, urban, educated counterparts. Besides, a girl, worldwide, is more likely to become pregnant under circumstances of social exclusion, poverty, marginalization and gender inequality, where she is unable to fully enjoy or exercise her basic human rights, access to health care, schooling, information, services and economic opportunities.

Jensen and Thornton (2003) maintained that many women in the developing world were subject to marriage at an early age. These disenfranchised women often lacked any say in the choice of their marriage partners. The incidence varies widely, from a high of $70 \%$ in south Asia to a low of $30 \%$ in South East Asia. Women who marry young tend to have less education and begin childrearing earlier and have less decision-making power in the household. They are also more likely to experience domestic violence. Similarly, according to UNFPA (2013), in every region of the world, impoverished, poorly educated and rural girls are more likely to become pregnant than their wealthier, urban, educated counterparts. Girls who are from an ethnic minority or marginalized group, who lack choices and opportunities in life, or who have limited or no access to sexual and reproductive health, including contraceptive information and services, are also more likely to become pregnant. Every year in developing countries, 7.3 million girls under the age of 18 give birth. Most $(95 \%)$ of the world's births to adolescents occur in developing countries.

Raj, Saggurti, Balaiah, and Silverman (2009) mentioned that child marriage is a substantial barrier to social and economic development and a primary concern for women's health. They assessed the prevalence of child marriage (before 18 years) in young adult women in India, and the associations between child marriage and women's fertility and fertility-control outcomes. Data from the National Family Health Survey-II (2005-06) were limited to a sample of Indian women aged 20-24 years $(n=22,807)$, of whom 14,813 had been or were ever-married. Prevalence of child marriage was estimated for the whole sample. About $44 \cdot 5 \%$ of women aged 20-24 years were married before age 18 years, $22.6 \%$ were married before age 16 years, and about three percent were married before age 13 years.

Choe, Thapa and Mishra (2005) examined age patterns of first marriage and motherhood and covariates of early marriage, delayed consummation of marriage and early motherhood in Nepal using data from the 2000 Nepal Adolescent and Young Adult Survey (NAYA). Both unmarried and married male and female youths (age 14-22) were included in the survey. The analysis was based on 2800 urban youths and 5075 rural youths with complete information on the variables examined. As per the survey, the early marriage and early motherhood are quite common among Nepalese women, especially in rural areas with the need to focus on less educated female youths in the Terai region to reduce the reproductive health risks associated with early marriage and childbearing.

Using large-scale youth surveys conducted in Indonesia in 1999 and in Nepal in 2000, Choe, Thapa and Achmad (2001) examined age patterns of marriage and motherhood for males and females, and factors associated with the pace of marriage and pace of motherhood in these two countries. Early marriage before age 18 among females is common in rural Indonesia and in both urban and rural areas of Nepal. According to them, majority of rural Nepalese females marry before age 18 and child marriages (before age 15) are common in Nepal. In Nepal, 17\% of urban females and $26 \%$ of rural females marry before age 15 but in Indonesia, only two percent of urban females and eight percent of rural females do so. In Nepal, the background factors affect 
females' pace of marriage and pace of motherhood somewhat differently. Females with primary level education are marrying at much slower pace than females with no education. The effects of ecological region (Terai vs. Hill) and development region are much stronger on the pace of marriage than on the pace of motherhood.

Gautam (2013) conducted a research on "Age at marriage and fertility in Tharu community" in Bardiya with the objective of identifying the pattern of age at marriage and fertility level in Tharu women. She interviewed purposively sampled 104 women there using interview schedule. She found that nearly $83 \%$ of the respondents got married at the age of $15-$ 19 years. The mean age at marriage was 16.6 years. Similarly, Dangi (2017) conducted a study on "Early pregnancy and its effects on maternal and child health of Dalit community in Bardiya with the aim of identifying the effect of early pregnancy on maternal and child health of Dalit community. He interviewed randomly selected 106 respondents using structured interview schedule. He found that $62 \%$ of the respondents got married at the age of 17-18 years. Majority (71\%) of the respondents had faced reproductive health problems due to early pregnancy.

\section{METHOD}

This study is based on mixed method as both qualitative and quantitative methods had been used to obtain required data/information. Besides, it follows the descriptive study design. In Bardiya, Tharu, Madhesi and Muslim community were selected. Similarly, in Dailekh, Dalit, Janajati and a cluster of Brahmin/Chhetri community had been selected. The households were sampled from the clusters of three wards of Badhaiyatal Rural Municipality in Bardiya and Dullu Municipality in Dailekh for household survey. Total 167 households (66 households from Dailekh and 101 households from Bardiya) had been randomly selected at 15\% sampling from 1110 (439 in Dullu, Dailekh and 671 in Badhaiyatal, Bardiya). Nepa, Chhiudi and Gamaudi from Dullu Municipality in Dailekh and Jamuni, Sorhawa and Mainapokhar from Badhaiyatal Rural Municipalty in Bardiya were the study area of this research.

In terms of qualitative work, key stakeholders, adolescents and right holders were selected for total three Focus Group Discussions (FGDs) in each district. For key stakeholder, police, health personnel from Health Post (HP), teachers from school, School Management Committee (SMC), ward secretary, local authority, Village Child Protection Committee (VCPC), community mediation centre, Social Mobilizer (SM), Female Community Health Volunteer (FCHV) were selected for the purpose. For adolescents, six boys and six girls were selected from each district. Similarly, members from Citizen Awareness Centre, Mother's Group, Child Club, Youth Club, political party and religious persons were taken as the participants of FGD with right holders. Finally, eight Key Informants' Interviews (KIIs) had been conducted with the district level key stakeholders on ECM from each district. They were from District Police Office (DPO), District Coordination Committee (DCC), District Women and Children Officer (DWCO), Child Protection Officer (CPO), District Public Health Officer (DPHO), District Education Officer (DEO), District Attorney's Office and Child Helpline Agency.

A detailed Household Interview Schedule had been developed for collecting quantitative data. Similarly, detailed checklists had been prepared for qualitative data collection regarding FGD with local key stakeholders, adolescents, and right-holders, KII with district level stakeholder and In-depth Interview (IDI) with early/forced child marriage (ECM) survivors. While preparing the tools, closed discussion with the senior staff of Aawaaj (an NGO in Surkhet 
working for child right) had been conducted. All the tools had been developed both English and Nepali for the convenience of field work and reporting purposes.

Four Research Assistants, working in the field of child right and child marriage and having sound prior experience on child marriage and child right as well as field survey, had been deputed for assisting field work of household survey, FGD, KII and IDI. The Household survey data had been entered in the computer in SPSS program. Then the data were tabulated and calculated using SPSS and MS Excel program. Besides, the qualitative reporting was done on the basis of content analysis. Based on the outputs of the analysis of both qualitative and quantitative data this research article has been prepared.

\section{RESULTS AND DISCUSSION}

Universality of marriage still prevails in Nepal and child marriage seems to be persistent in the country. Based on the household survey of this study, $94 \%$ of the respondents reported that there had the prevalence of case of ECM in their household. According to FGD with local stakeholder, there is high prevalence of ECM in Bardiya especially in Madhesi community. In Bardiya, child marriage has been occurring in especially in the age of 16-18 years, but it ranges 13 years to 18 years. Similarly, in Dailekh, there is high prevalence of ECM especially, in Dalit and economically poor community. There is a case of abortion at age of 15 at sub-health post in Dailekh. Sometimes ECM is seen also at age of 10 in Dailekh.

As per the FGD with adolescents, there is prevalence of ECM as about $30 \%$ of the adolescents are married in Bardiya and about 35\% in Dailekh. Mostly girls are married at the age of 14 and boys at the age of 16/17 years in the community. Similarly, according to FGD with right holders; there is the high prevalence of ECM in Bardiya. Self-elopement is very popular. However, arrange marriage is prevalent in Madhesi and Muslim community.

\section{Age at Marriage}

In the study area, majority $(64 \%)$ of the marriage $(\mathrm{N}=766)$ had taken place at the age of 15-19 years for the household population of 10 years and over. Besides, about $23 \%$ of the marriage had occurred at 10-14 years. Similarly, 10\% of the marriage had happened at 20-24 years. Merely about two percent of the marriage had taken place at 25 years and over. In this way, nearly $89 \%$ of the marriage had taken place by 19 years for the population whose current age is 10 years and over. Average value of age at first marriage is 16.5 years.

Table 1. Age at First Marriage (10 years and over)

\begin{tabular}{lcccccc}
\hline \multirow{2}{*}{$\begin{array}{l}\text { Age at first marriage } \\
\text { (in Years) }\end{array}$} & \multicolumn{2}{c}{ Male } & \multicolumn{2}{c}{ Female } & \multicolumn{2}{c}{ Total } \\
\cline { 2 - 7 } & No. & Percent & No. & Percent & No. & Percent \\
\hline Under 10 & 2 & 0.6 & 11 & 2.6 & 13 & 1.7 \\
$10-14$ & 54 & 16.3 & 122 & 28.1 & 176 & 23.0 \\
$15-19$ & 209 & 63.0 & 280 & 64.5 & 489 & 63.8 \\
$20-24$ & 53 & 16.0 & 21 & 4.8 & 74 & 9.7 \\
25 and over & 14 & 4.2 & 0 & 0.0 & 14 & 1.8 \\
\hline
\end{tabular}




\begin{tabular}{lcccccc}
\hline \multirow{2}{*}{$\begin{array}{l}\text { Age at first marriage } \\
\text { (in Years) }\end{array}$} & \multicolumn{2}{c}{ Male } & \multicolumn{2}{c}{ Female } & \multicolumn{2}{c}{ Total } \\
\cline { 2 - 7 } Total & No. & Percent & No. & Percent & No. & Percent \\
\hline & 332 & 100.0 & 434 & 100.0 & 766 & 100.0 \\
\hline
\end{tabular}

Comparing the data sex wise, about $16 \%$ of the male and $28 \%$ of female were found married at the age of $10-14$ years. About $65 \%$ female and $63 \%$ of the male had married at the age of 15-19. Comparatively the share of male for early marriage is rather lower than female.

\section{Age at Marriage by Caste}

Out of $128 \mathrm{Brahmin} /$ Chhetri persons, $17 \%$ were married at the age of $10-14$ years, about $56 \%$ in $15-19$ years and $20 \%$ in age $20-24$ years. Similarly, among 125 Dalit, $81 \%$ of marriage had taken place in $15-19$ years. In addition, about $10 \%$ had married in 10-14 years. Only nine percent marriage had taken place at 20-24 years. Among 127 Tharu, $83 \%$ marriage had occurred in 15-19 years and seven percent in 10-14 years. Just 10\%had married at 20-24 years.

Among 92 Janajati (hill) persons, 64\% marriage had taken place in $15-19$ years and $16 \%$ in 10-14 years. Similarly, $13 \%$ marriage had taken place in $20-24$ years and just about five percent in 25 and over. Among 170 Madhesi persons, four percent had married in less than 10 years, 39\% in $10-14$ and $52 \%$ in $15-19$ years. In this way, $96 \%$ marriage had taken place by age of 19 . Finally, in 124 Muslim persons, about three percent marriage had taken place in less than 10 years, $41 \%$ in $10-14$ years and $51 \%$ in $15-19$ years. It means $95 \%$ of the marriage had taken place by age of 19 in Muslim community. Just five percent of the marriage had place after 20 years in that community. In this way, Just $26.5 \%$ Brahmin, about nine percent Dalit, $10 \%$ Tharu, about $18 \%$ Janajati (hill), four percent Madhesi, and five percent Muslim people had been married at the age 20 years and over (Table 2 ).

\section{Age at Marriage by Education}

For 'under 10' years of age at marriage, illiterate persons share highest (46\%). For 1014 years, total of basic literate and basic level educated persons share highest $(71 \%)$. For illiterate and basic literate persons, the highest share of marriage had taken place less than 10 and 10-14 years. For 15-19 years, basic level educated persons had highest concentration (44\%). Detail has been shown in Table 3 . 
Table 2. Age at First Marriage by Caste of Population (10 years and over)

\begin{tabular}{|c|c|c|c|c|c|c|c|}
\hline \multirow[t]{2}{*}{ Caste } & & \multicolumn{5}{|c|}{ Age at first marriage } & \multirow[b]{2}{*}{ Total } \\
\hline & & Under10 & $10-14$ & 15-19 & $20-24$ & $\begin{array}{c}25 \\
\text { over }\end{array}$ & \\
\hline \multirow[t]{2}{*}{ Brahmin/Chhetri } & No. & 1 & 22 & 71 & 26 & 8 & 128 \\
\hline & $\%$ & $.8 \%$ & $17.2 \%$ & $55.5 \%$ & $20.3 \%$ & $6.2 \%$ & $100.0 \%$ \\
\hline \multirow[t]{2}{*}{ Dalit } & No. & 0 & 12 & 102 & 11 & 0 & 125 \\
\hline & $\%$ & $.0 \%$ & $9.6 \%$ & $81.6 \%$ & $8.8 \%$ & $.0 \%$ & $100.0 \%$ \\
\hline \multirow[t]{2}{*}{ Tharu } & No. & 0 & 9 & 105 & 13 & 0 & 127 \\
\hline & $\%$ & $.0 \%$ & $7.1 \%$ & $82.7 \%$ & $10.2 \%$ & $.0 \%$ & $100.0 \%$ \\
\hline \multirow[t]{2}{*}{ Janajati (Hill) } & No. & 1 & 15 & 59 & 12 & 5 & 92 \\
\hline & $\%$ & $1.1 \%$ & $16.3 \%$ & $64.1 \%$ & $13.0 \%$ & $5.4 \%$ & $100.0 \%$ \\
\hline \multirow[t]{2}{*}{ Madeshi } & No. & 7 & 67 & 89 & 7 & 0 & 170 \\
\hline & $\%$ & $4.1 \%$ & $39.4 \%$ & $52.4 \%$ & $4.1 \%$ & $.0 \%$ & $100.0 \%$ \\
\hline \multirow[t]{2}{*}{ Muslim } & No. & 4 & 51 & 63 & 5 & 1 & 124 \\
\hline & $\%$ & $3.2 \%$ & $41.1 \%$ & $50.8 \%$ & $4.0 \%$ & $.8 \%$ & $100.0 \%$ \\
\hline \multirow[t]{2}{*}{ Total } & No. & 13 & 176 & 489 & 74 & 14 & 766 \\
\hline & $\%$ & $1.7 \%$ & $23.0 \%$ & $63.8 \%$ & $9.7 \%$ & $1.8 \%$ & $100.0 \%$ \\
\hline
\end{tabular}


Table 3. Age at First Marriage by Education of Population (10 years and over)

Educational status

Age at first marriage

\begin{tabular}{|c|c|c|c|c|c|c|c|}
\hline & & & & & & & \multirow[b]{2}{*}{ Total } \\
\hline & & Under10 & $10-14$ & $15-19$ & $20-24$ & $25 \&$ over & \\
\hline \multirow[t]{2}{*}{ Illiterate } & No. & 6 & 47 & 81 & 8 & 3 & 145 \\
\hline & $\%$ & $46.2 \%$ & $26.7 \%$ & $16.6 \%$ & $10.8 \%$ & $21.4 \%$ & $18.9 \%$ \\
\hline \multirow[t]{2}{*}{ Basic literate } & No. & 5 & 63 & 124 & 11 & 3 & 206 \\
\hline & $\%$ & $38.5 \%$ & $35.8 \%$ & $25.4 \%$ & $14.9 \%$ & $21.4 \%$ & $26.9 \%$ \\
\hline \multirow[t]{2}{*}{ Basic level (1-8) } & No. & 2 & 62 & 217 & 26 & 2 & 309 \\
\hline & $\%$ & $15.4 \%$ & $35.2 \%$ & $44.4 \%$ & $35.1 \%$ & $14.3 \%$ & $40.3 \%$ \\
\hline \multirow[t]{2}{*}{ Secondary } & No. & 0 & 3 & 60 & 23 & 4 & 90 \\
\hline & $\%$ & $.0 \%$ & $1.7 \%$ & $12.3 \%$ & $31.1 \%$ & $28.6 \%$ & $11.7 \%$ \\
\hline \multirow[t]{2}{*}{ Bachelor } & No. & 0 & 1 & 5 & 4 & 2 & 12 \\
\hline & $\%$ & $.0 \%$ & $.6 \%$ & $1.0 \%$ & $5.4 \%$ & $14.3 \%$ & $1.6 \%$ \\
\hline \multirow[t]{2}{*}{ Master } & No. & 0 & 0 & 2 & 2 & 0 & 4 \\
\hline & $\%$ & $.0 \%$ & $.0 \%$ & $.4 \%$ & $2.7 \%$ & $.0 \%$ & $.5 \%$ \\
\hline \multirow[t]{2}{*}{ Total } & No. & 13 & 176 & 489 & 74 & 14 & 766 \\
\hline & $\%$ & $100.0 \%$ & $100.0 \%$ & $100.0 \%$ & $100.0 \%$ & $100.0 \%$ & $100.0 \%$ \\
\hline
\end{tabular}

\section{Contributing Factors of ECM}

There is no single factor that contributes the early and child marriage. A wide range of factors place girls at risk of child marriage. The persistence of gender inequality and social norms that value women less and consider them to belong to their husband's family, the ineffective implementation of existing legal provisions prohibiting child marriage, and barriers in accessing legal remedies can be taken major ones. Similarly, parents decide to marry their daughters at an early age because marriage is viewed as a means to protect girls from sexual violence and premarital sexual relations, ward off any perceived dishonor to the family that may be caused by inter-caste marriage and restore a sense of family honor in cases of sexual violence. Besides, parents often arrange child marriages with the intention of reducing the financial burden on the family as lower dowry is expected for younger brides, particularly in communities living in the Terai region (Centre for Child Right, 2016). 


\section{Poverty and self-elopement as the cause of ECM}

Ms Tharu, 20, from Bardiya, reported, "When I was studying in $9^{\text {th }}$ grade in a school, I fell in love with a boy. We were neighbors and were studying in the same school. As we were young (I was 15 years), we married with self-elopement because of the fear that parents might not accept our marriage at that age. The main cause of our ECM was the love and the weak financial condition of my home".

\section{Dowry as the cause of ECM}

Mr. Shekh, 23, from Bardiya, told "Most of the marriage takes place in 16-18 years in this community because of fear of increase of dowry with the increase of age of girls."

In the response to the cause of ECM, about $93 \%$ of the household respondents mentioned 'lack of awareness'. About three-fifth of them reported 'imitation' as the cause. As the love marriage (self-elopement) is popularly prevalent in the study area, $54 \%$ of the household respondents reported it as the cause of ECM. Similarly, 35\% mentioned ICT media (mobile and internet) as its cause. Other causes were low-economic level (reported by $32 \%$ ), religious cause (reported by $28 \%$ ) and the guardian's pressure (reported by $22 \%$ ). In this way, we can infer that there are various determining factors of the ECM.

Because of the lack of awareness on the effects of ECM, its legal provision, child right and reproductive health, most of the cases of ECM have been occurred. According to adolescents in the FGDs, love affair and love marriage, imitation, taking the girls as financial burden, sociocultural tradition in Madhesi community to take early marriage of the daughter as sacred task, family pressure and thinking of sister-in-law (Buhari) as free labor are some causes of ECM. Besides, due to unstable mental and psychological state of persons during adolescence period, they emotionally decide to marry when they like their partners with the attraction of tie with welloff family. Similarly, lover's pressure, mobile, peer pressure, Face book, parents/grand-parents are also other contributing factors of ECM. Participants of FGD with right-holders and local stakeholders had also reported similar causes. Participants of FGD with right-holders also mentioned similar causes. Besides, they mentioned that violent behavior of parents and lack of love and affection to children in the family can also be taken as other determining factor of ECM.

In terms of responsible person for ECM, a question "Who are the responsible person for ECM in your family/community?" had been asked to household respondents in the survey. About $68 \%$ respondents mentioned father and mother as responsible persons for ECM. Similarly, 56\% blamed the self-elopement for ECM. Besides, 39\% told that the lovers (males or females) themselves were responsible for ECM. Some (29\%) saw the friend as the responsible for ECM. Similarly, on the question, "Who must have the right to decide about the marriage and its age?" most $(67 \%)$ of the respondents reported that the father must have the right for it. There is the predominance of male in authority of household because just about one-tenth of them told that mother deserves the right for it. About one-fifth of them had mentioned the marriage must be decided by the person own-self. Rest $80 \%$ could not mention right person to decision about it. It shows that there is lack of proper knowledge in the community people regarding marriage and its main deciding person (Chart 1). 


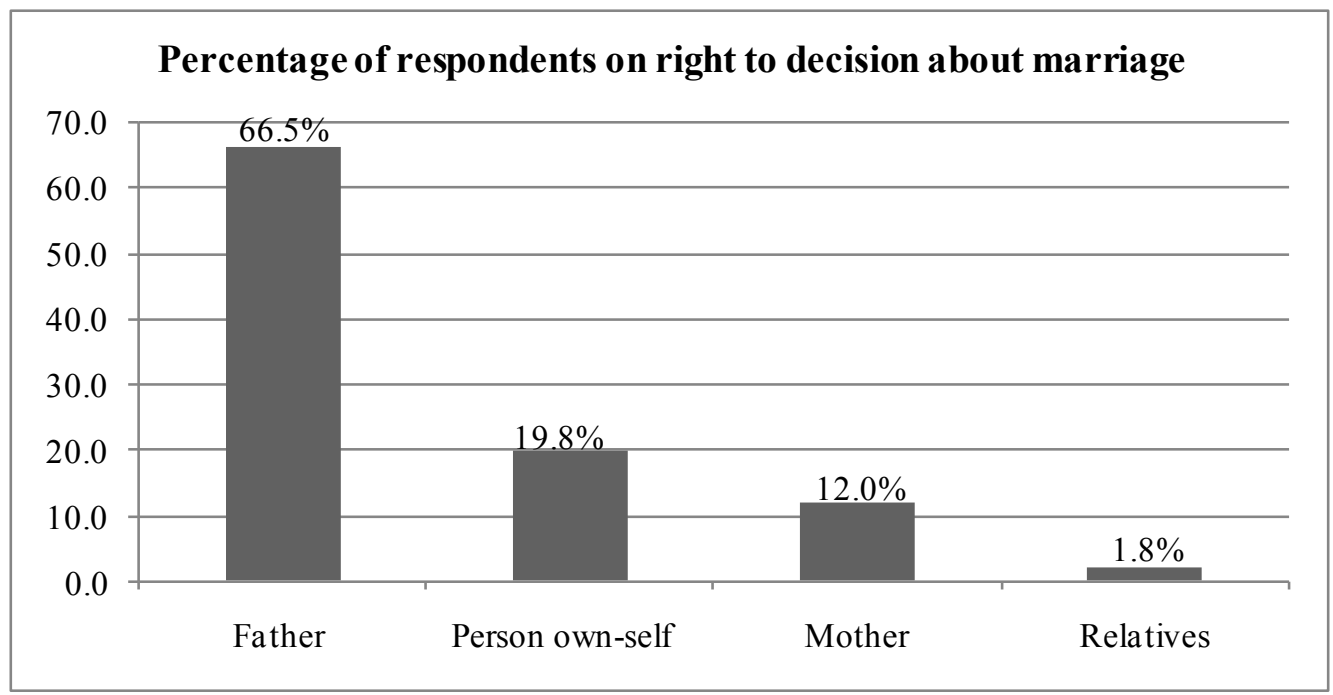

Figure 1. Percentage of Respondents on Right to Decision on Marriage

Similarly, proper knowledge on the legal provision regarding the marriage is necessary for the community people. As per the respondents of Household Survey, only $29 \%$ could report the correct legal age at marriage that must take place 20 years onward in Nepal. Rest $71 \%$ of them could not mention it correctly. In addition, majority $(60 \%)$ of them had heard about punishment regarding ECM. They knew the activity of ECM is punishable. However; they had no idea about the detail legal provisions on ECM. Rest $40 \%$ had not heard about it. It means that the community people need the legal awareness on ECM.

\section{Effects of ECM}

As per the FGD with adolescents, ECM survivors had been facing various RH problems: tearing vagina, heavy bleeding, prolonged labor, UP, risk of life, lack of adequate breast-milk and problem in child care. Similarly, they also suffer from unsafe sexual behavior, unwanted pregnancy, STIs, violence affecting on sexual organs. Similarly, low birth weight, vulnerable to infection and impaired physical and mental development and morbidity of children can also be the effect of ECM.

\section{Case Study: Loss of educational opportunity and morbid child due to ECM}

Sita B. K. (name changed), 21, from Dailekh, was forcefully taken by a boy in his home for the purpose of marriage at the time of 17 while studying in grade 9 . She wanted to continue the study and did not want to get married at that time and person. However, her mother accepted that event and convinced her father although he was opposing at first. Despite her strong desire to pursue the study, she could not do it because of child birth at 18 and family workload thereafter. The first child had low birth weight $(2 \mathrm{~kg})$ and became morbid till two years.

As per the FGD with right-holders, there are various effects of ECM. The person at individual level, experiences the lack of continuity in education, lack of affection, scolding in 
trivial matter, effect in reproductive health, effect in physical growth and development, possibility of polygamy, risk of life of mother and child, risk of suicide, unwanted pregnancy, unsafe abortion and unemployment. At family level, it creates economic burden, irresponsible with family, tension, family conflict, quarrel, and feeling of no cooperation due to dowry related causes. Similarly, at community level, unnecessary interest to others' affair, deprivation of love and education of children affect the social dignity.

In order to assess the knowledge of respondents at household level, they were asked about the effects of ECM. Most $(87 \%)$ of them reported that the health-related problem is emerged due to ECM. Similarly, $86 \%$ of them took risked pregnancy as its effect. Besides, $65 \%$ reported the workload that the ECM survivors have to face. About $44 \%$ of them reported the effect as school dropout. Deprivation of opportunity and lack of opportunity for economically self-dependent was reported by about $36 \%$ and $29 \%$ respectively. In this way, there are various effects of ECM.

Out of 167 respondents, $11 \%$ mentioned that the maternal mortality had occurred in their household. Main cause was bleeding. Similarly, there was occurrence of child mortality in about $17 \%$ household within last five years as per the household respondents. Out of the total occurrence of child mortality, three-fourth (75\%) had occurred at the age of 15-19 years of mothers. On the question, "Did any woman experience miscarriage in this family within last five years?" $35 \%$ of the respondents mentioned 'Yes'. Out of that, $85 \%$ of the miscarriage had occurred at the age of 15-19 years. Rest (15\%) was in 20 years and beyond.

In terms of violence, most $(79 \%)$ of the respondents mentioned that domestic violence occurs due to ECM. Similarly, some (73\%) reported denial of resources whereas $71 \%$ told mental torture as the effect of ECM. About one-fourth of them reported sexual violence can be cased due to ECM. Other kinds of violence like physical violence and trafficking reported by $17 \%$ and $14 \%$ respectively. Just about two percent (3 persons) reported that any kind of the violence had not occurred in their household. A respondent mentioned that denial of house could be seen after quarrelling as the effect of ECM. In this way, there is the rare chance of educational continuity of the ECM survivors in the community as per the knowledge of household respondents because the survivors have to get earning to manage their family. It further deteriorates the socioeconomic status of ECM survivors and their children.

\section{Measures to prevent ECM}

There can be various measures to prevent ECM on the basis of place, time and situation. During FGD with right holders in Bardiya, a member of Mother's Group told, "There is little practice of information before the marriage or in the process of marriage and we are just informed in the marriage ceremony or the formalization of marriage. If the family members inform us before the formal process of marriage, we counsel the cases and family members not to formalize the marriage."

Similarly, ECM survivor Ms Tharu, (Badhaiyatal, Bardiya) during the in-depth interview told,

In order to control ECM, there must be strict legal action and effective implementation of law. Besides, the awareness program in school and community is necessary. Though I married at the age of 15, I suggest others avoidance as it is a legal crime and it also curtails pursuing of the study. The child 
protection program and compulsory schooling can also support the eradication of ECM.

In order to eradicate/prevent ECM, it is necessary to increase awareness. According to Household Survey, about $63 \%$ of the total respondents favored this measure. About $22 \%$ reported strong legal provision and implementation for preventing ECM because there is no hard punishment and effective implementation. Inclusion of ECM in school education and child protection program was reported by $11 \%$ and about three percent of the respondents respectively.

In FGD, the local stakeholders emphasized the role of Village Child Protection Committee (VCPC) members to counsel to prospective cases of ECM in home and community. Besides, they pointed the role of guardians should convince their children against ECM, its effects and the legal process regarding it. Community people could avoid the marriage ceremony of ECM to discourage it and can inform to Police.

In this way, as per the FGD, IDI and KII, IGA to households' people, mass awareness, strict implementation of law, parenting education, life skill education, formation and empowerment of local level structure with involvement of the local stakeholders and right holders are some important measures to control ECM. Besides, compulsory education up to 12 grade before marriage, controlled access of mobile to children, peer education with involvement of ECM survivors, establishment of local level information center, empower and mobilize clubs and VCPCs can also be conducted.

\section{Case Study: A good father can be a 'Role Model' against ECM campaign}

Ms Thapa, a 17-year student of class ten, is from Dullu -10, Dailekh. She got married at age of 16 as self-elopement without the consent of her parents; however, her parents are caring her in their own home along with her husband and supporting their education. Due to her young age, still her parents do not want to manage formal marriage ceremony.

Her father told that, "I would arrange the marriage of my daughter at age of 20, after her completion of school. As our Gurung culture, there is the right to marriage with or without the consent of parents called "Mama Cheli and Fupu Chela. My nephew and my daughter got married according to our culture as well as with their interest". And he added more; "However, I will care both of them at my own house and send my daughter only after formal marriage ceremony after age of 20 Because ECM is social crime and we have to stop to it".

\section{Case Study: At the age of 22 years, total six births out of which two died}

Maina Kalawar (name changed), 22, is one of the characters in a community of Bardiya. She was born as second daughter in a very poor family with very small land just for small hut. Her parents gave birth to a son after five daughters. In order to maintain the means of surviving, her father had a small tea and sweet shop. For the sake of escaping from the burden of guardianship due financial problem, her father arranged the marriage of her elder sister at the age of 15 and sent India. After some months of elder sister's marriage, he also arranged Maina's marriage while she was 13 and studying in grade two nearby primary school. He further arranged marriage of another younger sister. In this way, he arranged marriage of her daughters in a very early age even within a very short span. He, then, died of heartattack. However, her mother had not got marriage registration and citizenship certificate. In that situation, one of her neighbors threatened and captured their land making the registration in own name. In that very critical situation, her mother went her maternal home to India taking Maina's two sisters and a brother. 
When Maina got married at the age of 13 with a boy of 15 studying in grade five, she reached her husband's home, where her husband had six brothers. Her husband was second son of his parents. Therefore, she had huge work burden of that joint family. She experienced violence from her husband, parents-in-laws and elder sister-in-law when she could not complete the drudgery. Despite this, she became pregnant after three months of her marriage but her first pregnancy termed at fetal death. Out of her six pregnancies at the age of 22 years, she lost two due to pregnancy at the very young age, lack of adequate birth spacing and proper care. Due to the lack of proper care and nutritious diet, her children are malnourished. Consequently, she also looks very weak and pale despite her young age of 22 .

\section{CONCLUSION}

Despite the declaration of 'literate district', illiteracy existed significantly in the study districts with higher share in female. Predominance of joint family and higher share of population with agricultural dependence for source of family income was found in the sampled households. Lack of own cultivable land and inadequacy of yielding caused the poverty in the sampled households. Firewood was main source of fuel. Very nominal share of household had RCC building and access to piped water.

Most of the household respondents had reported that their household had early and child marriage (ECM) ranging from 13-18 years. Majority (64\%) of the marriage had taken place at the age of 15-19 years for the population of 10 years and over as mean age at marriage was 16.5 years. Dalit, Madhesi and Muslim community had high prevalence of ECM due to illiteracy and poverty. There was close relationship with level of education and the prevalence of ECM. The higher the level of education, the lower was the prevalence of ECM.

Lack of proper awareness about legal provision regarding marriage and the negative effects of ECM, it is prevalent. Similarly, there is the low prevalence of marriage registration. Besides, misuse of ICT media (mobile and Internet), self-elopement, imitation, taking the girls as burden, socio-cultural tradition in Madhesi community on early marriage of daughter as sacred task and less burden of dowry, family pressure, taking sister-in-law (Buhari) as free labor are some causes of ECM. Similarly, lover's pressure and decision of parents/grandparents are also other contributing factors of ECM.

Because of ECM, the survivors were facing various RH problems: tearing vagina, heavy bleeding, prolonged labor, UP, lack of adequate breast-milk and problem in child care as well as maternal and child mortality. Similarly, they also suffer from unsafe sexual behavior, unwanted pregnancy, unsafe abortion, STIs, domestic and sexual violence affecting on sexual organs. At family level, it creates economic burden, family conflict, quarrel, and feeling of no cooperation due to dowry related causes.

On Preventing ECM various measures like mass awareness, strict implementation of law, parenting education, life skill education, income generating activities (IGAs) to household people, the formation of local level structure with involvement of the local stakeholders and right holders, compulsory education up to 12 before marriage, control access of mobile to children can be taken. Besides, peer education, establishment of local level information centre, empower and mobilize clubs and VCPCs had also been reported as other measures. Therefore, the case of ECM needs the attention of the policy maker. 


\section{REFERENCES}

Aawaaj (2016). Combating early/forced child marriages in rural Bardiya and Dailekh Mid-Western Nepal. (A proposal submitted to ECPAT Luxemburg).

CBS. (2016). Multiple indicator cluster survey 2014 (Final Report). Kathmandu: CBS.

Choe, M. K., Thapa, S., \& Achmad, S. I. (2001). Early marriage and childbearing in Indonesia and Nepal. Population Series, No. 108-15, retrieved November 30, 2017 from http://hl-128-171-5722.library.manoa.hawaii.edu/bitstream/10125/3629/1/POPwp10815.pdf

Choe, M. K., Thapa, S., \& Mishra, V. (2005). Early marriage and early motherhood. Nepal. Journal of Biosocial Science, Volume 37, Issue 2, March 2005, pp. 143-162.

Dangi, B. (2017). Early pregnancy and its effects on maternal and child health of Dalit community. A Masters' Degree thesis submitted to Department of Population Education, Surkhet Campus (Education), Tribhuvan University, Nepal.

Gautam, P. (2013). Age at marriage and fertility in Tharu community. A Masters' Degree thesis submitted to Department of Population Education, Surkhet Campus (Education), Tribhuvan University, Nepal.

Jensen, R., \& Thornton, R. (2003). Early female marriage in the developing world. Gender \& Development, 11(2), 9-19.

Ministry of Health, Nepal; New ERA; and ICF. (2017). Nepal demographic and health survey 2016: Key indicators. Kathmandu: Author. Retrieved from https://dhsprogram.com/pubs/ pdf/PR88/PR88.pdf

Ministry of Women, Children and Social Welfare [MWCSW] (2016). National strategy on ending child marriage. Kathmandu: MWCSW

National Planning Commission [NPC] (2017). The $14^{\text {th }}$ plan. Kathmandu: NPC.

Plan International, Save the Children \& World Vision International Nepal (2014). Child marriage in Nepal (research report) Retrieved from http://www.wvi.org/sites/default/ files/Child\%20Marriage\% 20in\%20Nepal-\%20Report.pdf

Raj, A., Saggurti, N., Balaiah, D., \& Silverman, J.G. (2009). Prevalence of child marriage and its effect on fertility and fertility-control outcomes of young women in India: a cross-sectional, observational study. The Lancelet, Volume 373, Issue 9678, May-June 2009, Pages 1883-1889.

Save the Children (2014). Too young to wed. Retrieved from http://www.savethechildren.org /atf/cf/\%7B9def2ebe-10ae-432c9bd0df91d2eba74a\%7D/TOO_YOUNG_TO_WED_REPORT_ 0714.PDF

The Centre for Reproductive Rights (2016). Ending impunity for child marriage in Nepal. Retrieved from http://nepal.unfpa.org/sites/default/files/pub-pdf/Ending\%20Impunity \%20for\% 20Child\%20 marriage $\% 28$ final $\% 29$ 25Nov16.pdf

UNFPA (2013). The state of world population 2013: Motherhood in childhood, facing the challenge of adolescent pregnancy. Retrieved from http://www.unfpa.org/sites/default/ files/pub-pdf/ENSWOP2013.pdf

UNFPA. (n. d). Proximate determinants of fertility. Retrieved from http://papp.iussp.org/index. html

UNFPA. (n.d.). Child, forced and early marriage. Retrieved from http://nepal.unfpa.org/sites/ default/files/pub-pdf/Factsheet $\% 20$ child $\% 20$ marriage.pdf

Vandana. (2017). Child marriage under Hindu personal law: Factum valet or an Issue for protection of human rights of women, ILI Law Review (Summer Issue 2017), Vol. I http://ili.ac.in/pdf/paper1117.pdf 


\section{AUTHOR NOTE}

This article is based on the baseline survey on Combating early/forced child marriages in rural Bardiya and Dailekh Mid-Western Nepal, 2017 conducted by the author for Aawaaj (An NGO in Surkhet, Nepal).

PITAMBAR ACHARYA is a lecturer at Tribhuvan University in Nepal. As an experienced teacher and contributor, he has authored articles in various journals and magazines in addition to school and college level textbooks and reference books. He has also served as a teacher trainer in ICT, pedagogy, and HPE education. In addition, he has handled half a dozen research works on impact studies and baseline studies as a consultant. His areas of interest include reproductive health, gender, and higher education.

BENJAMIN H. WELSH, Ph.D. is an associate professor of higher education and urban educational leadership at Morgan State University. Dr. Welsh joined the faculty of Advanced Studies, Leadership, and Policy at Morgan State University in the spring of 2009. Prior to that, he served as assistant professor of educational foundations at Ball State University. Related positions that he has held include developmental English instructor at the Community College of Philadelphia, English teacher at Bartram High School in Philadelphia, and ACT Coordinator at the Philadelphia Job Corps Center. His dissertation focused on the research methods of the early educational researchers who were part of Stanford University's founding faculty circa 1890. What he uncovered was a eugenic ideology that appears to have been transmitted directly from the research methods into the fabric the American public-school system. Other teaching and research interests include white studies, multicultural education, the history of education, analytic philosophy of education, and the long-term impact of eugenics on our public schools. 